\title{
Moral Aspects of Imaginative Art in Thomas Aquinas
}

\author{
Piotr Roszak 1,*(D) and John Anthony Berry ${ }^{2}$ \\ 1 Faculty of Theology, Nicolaus Copernicus University, 87-100 Torun, Poland \\ 2 Faculty of Theology, University of Malta, Msida MSD 2080, Malta; john.berry@um.edu.mt \\ * Correspondence: piotrroszak@umk.pl
}

check for updates

Citation: Roszak, Piotr, and John Anthony Berry. 2021. Moral Aspects of Imaginative Art in Thomas Aquinas. Religions 12: 322. https:// doi.org/10.3390/rel12050322

Academic Editors: Manuel

Lázaro Pulido and

Ricardo Piñero Moral

Received: 27 March 2021

Accepted: 30 April 2021

Published: 1 May 2021

Publisher's Note: MDPI stays neutral with regard to jurisdictional claims in published maps and institutional affiliations.

Copyright: (c) 2021 by the authors. Licensee MDPI, Basel, Switzerland. This article is an open access article distributed under the terms and conditions of the Creative Commons Attribution (CC BY) license (https:// creativecommons.org/licenses/by/ $4.0 /)$.

\begin{abstract}
For Thomas Aquinas, the imagination, being one of the "inner senses", is a doorway to attain true knowledge. In this paper, we first analyze his lexicon in this regard (imaginatio and phantasia). Second, we discuss imagination as the subject matter of the intellectual virtues, which facilitate cognition and judgment. The development of imagination is the foundation of his vision of education not only on the natural but also on the supernatural level. Third, we explore Aquinas' moral assessment of imaginative art and finally its influence on shaping the character. This influence occurs on two levels: it is assessed from the perspective of charity, justice, prudence and purity, namely to what extent the art serves these values, whereas the second criterion is beauty.
\end{abstract}

Keywords: fine arts; virtue ethics; prudence; character; Thomism; architecture

\section{Introduction}

Thomas Aquinas explicitly notes the key role of a well-configured imagination in moral life. In his De Veritate, he notices that "a good preparation of the imagination causes a perfect intellectual cognition" (De Veritate, q. 14, a. 4, ad 5). It results from the interaction of individual elements, just like a body where many members cooperate in one action. At the same time, Aquinas is aware of the interactions that occur between the imagination and feelings that can push a person to certain actions. Sometimes imaginary evil can cause the appearance of certain feelings; a healing or a recovery, in that case, should therefore follow the act of purifying the imagination. Hence, the educational challenge will be an appropriate way of defining the principles of interaction of individual elements in order to build a mature moral personality (Martinez 2002).

In the context of imaginative art and the role it plays in shaping the character of a human being, Aquinas draws attention to several criteria that allow art to be assessed morally. The use of imagination in art is, on the one hand, an expression of enriching, with a more and more universal apprehension. Whereas, on the other hand, developing imagination in the form of art does not remain an area of fancy fantasy, assessed only through the prism of discussing the "limits" of art or the scope of freedom of the creator. There is a place for the virtues that regulate the operation of imagination and lead to its optimal functioning.

Among the publications on the issues of imagination and fantasy, we can find many studies in the field of epistemology (Manzanedo 1978; Gilson 1994) or psychology (Matula 2002), as well as art in general (Simpson 2018), but our attempt here is to focus on the role of imaginative art in human moral life.

In this article, after analyzing the terminological aspects of Aquinas' treatment of imagination, we demonstrate the significance of imagination for achieving the virtue and a well-ordered moral life. Finally, we explore the moral assessment of imaginative art, which is frequently treated as unbound from ethics, but remains important for the process of shaping character. 


\section{Two Sides of Imagination}

What today is understood as imagination in Thomas Aquinas' work can be described by two Latin terms of different meanings: phantasia and imaginatio. The former is often used by Aquinas to express the opposite of reality; for instance, the real body and the phantom (corpus phantasticum) in the context of Christ's resurrection or the influence of the evil spirit on the imaginary sphere, stimulating evil actions (Matula 2002, p. 172). In Aquinas' corpus, it has negative connotations (close to illusions). Another manifestation of the activity of phantasia is the "presenting of something" (apparitio), which depends on the act of the will and in this manner is different to opinion (Sentencia De anima, lib. 3 1. 6 n. 14).

The second mentioned term (imaginatio) makes reference to the "inner senses" of his realistic anthropology and remains an indispensable disposition to attain true knowledge (Stępien 2013, p. 79). In this way, the imagination-contrary to modern connotations-does not mean imagining something unrecognizable for which no one assumes any responsibility, but creating images of things that help the soul to shape itself (De veritate, q. 10 a. 6 ad 5). Following Michał Zembrzuski, we can distinguish two levels of activity of such imagination in Aquinas: (1) joining or disconnecting, due to which new forms are created that were not previously conceived, and (2) a certain activity appears which Aquinas describes as formatio (Zembrzuski 2015, pp. 222-27).

For St. Thomas, imagination is, above all, an expanded perception of the world, which exceeds what the senses can perceive at a given moment (Bauerschmidt 2009, 2010). However, there may be confusions, which Aquinas describes as imaginatio confusa (In 2 Sent., d. 20 q. 2 a. 2 ad 4) or falsa imaginatio (In 1 Sent., d. 17 q. 2 a. 2c.; In 1 Sent., d. 8 q. 5 a. 3c, where Aquinas even speaks about duplex falsa imaginatio), which is the case, for example, when someone falsely imagines the growth of love in a quantitative way, as if something is "added"-like the rise of temperature. Or, when distance or differences in the hierarchy of spiritual beings are treated spatially, imagining the distance between physical bodies (In 2 Sent., d. 9, q. 1, a. 2, ad 6): if someone imagines that the soul is in the body, as in a place (In 1 Sent., d. 8 q. 5 a. 3c) or when he reduces the soul to a body, because he cannot imagine a spiritual reality. All these errors result from the fact that there is a deficit of reason and the imagination is deprived of the manuductio of reason. In this respect, Aquinas encourages the development of imagination that does not "stretch" reality. This educational process could be expressed by the triple famous Latin phrases, which make reference to the medieval scholastic formulas (e.g., credo ut ... ): Imagino ut intelligat, Imagino ut repraesentat, Imagino ut sentiat.

\subsection{Imagino ut Intelligat}

Imagination is an expression of the ability of the intellect and that is why it is better developed in humans than in animals (De potentia, q. 2 a. 2c). Because of human rationality, the imagination in humans is greater, not smaller (In 3 Sent., d. 13 q. 2 a. 1c). Difficulties in imagining something can appear and they are caused, as Aquinas explains, by the difficult object of cognition. The creation of these ideas is connected with the work of the senses, on which it directly depends:

"The apprehension of the imagination is subject to the ordering of reason, in proportion to the strength or weakness of the imaginative power. For that the human being is unable to imagine the things that reason considers, either because they cannot be imagined, such as incorporeal things; or because of the weakness of the imaginative power, due to some organic indisposition." (ST I-II, q. 17 a. 7 ad 3-trans. https:/ / www.newadvent.org (accessed on 30 April 2021))

Imagination is not transient, but remains in the subject as the fundamentum intellectualis operationis (Super De Trinitate, pars 3 q. 6 a. 2 ad 6), always assumed in every intellectual activity and efficiency. Gathering imaginative impressions is a treasure that determines the quality of cognitive processes, and thus indirectly affects character and builds it (Contra Gentiles, lib. 2 cap. $74 \mathrm{n}$. 2). This is because imagination stimulates thinking, but it is also able to distort it (ST I, q. 63 a. 3c). That is why imagination is needed in order for certain 
reasonings to be presented in all consequences. In any case, it remains an indispensable tool for shaping intellectual culture and is a pre-requisite for the proper work of reason, which Aquinas explains in the treatise on passions:

"Using reason requires the proper action of the imagination and other sensory powers that use body powers. Therefore, bodily transformation interferes with the use of reason, hindering the operation of the imagination and other sensory powers." (ST I-II, q. 33 a. 3 ad 3)

At the same time, Aquinas points out that the easiness of accumulating sensations and forming them in phantasmata does not always go with the good of judgment; "what is caused by defectiveness in the mind, mainly due to the defectiveness of the system in the common sense that fails in the assessment of the created notions and observations" (S. Th., II-II, q.51, a.3c; Mróz 2018). The act of imagination is necessary for the abstraction from the material brought by the external senses, but Aquinas emphasizes that it must be a very intense (vehemens) experience of the imaginary power of the human being (De veritate, q. 13 a. 3 ad 5).

\subsection{Imagino ut Repraesentat}

In the opinion of Aquinas (who follows Aristotle in this respect), "art imitates nature" (In Physic., lib. 2 1. 13 n. 4), although "nature" does not have to be limited to the objective and real; it can also include the subjective and ideal. At the same time, one can have different representations from the same things, as it can be seen in a language that, through metaphors, represents a lot of things. Such perception of art that is about representation is not a simple matching of elements, but a creative discovery of connections and multiple aspects. In this way, art shapes a diverse approach to the same reality, extracting the richness of apprehensions and stimulating a multidimensional approach.

In his educational practice, Aquinas constantly appeals to the listener's imagination, stimulates and directs it. The lack of such imagination inhibits the development of the human person and of science. He accuses the ancient philosophers of not being able to go beyond direct imagination, closing themselves in their diagrams and not making the effort of analogous knowledge (ST I, q. 75, a.7c). Analogy is one of the pillars of Aquinas' thinking: in reflections on objects of cognition that go beyond sensory experience, it suggests discovering similarities, not to treat them as simple mappings, but to see them as "similar dissimilarities" (Platovnjak 2018; Roszak 2020; Lazaro-Pulido 2019). In his works, it is often possible to find incentives to imagine some complex abstract issues (hence so many metaphors, imaginary rhetorical figures in Summa Theologiae). This diagnosis goes hand in hand with what Rowan Williams recently called "illiteracy of the imagination", which does not see the world differently than just two-dimensional (Waller 2018). Imagination and art will be an incentive for the human person to build a picture of the world that will be open. Thus, it is about a framework in which it is possible to understand the whole world where science and thinking "works" (Tabaczek 2020; Oleksowicz and Roszak 2021).

\subsection{Imagino ut Sentiat}

The Polish poet Zbigniew Herbert drew attention to another aspect of developing his imagination. In one of his poems "Mr. Cogito and the imagination", he indicates the use of imagination as a "tool of compassion", the ability to "comprehend the whole". This is the understanding of processes and phenomena, not just the particular, but universals. It is in the service of grasping the "uncertain brightness" which lightens a person, but is unable to develop due to the lack of creativity in the imagination. Imaginary art can be a bypass for thoughts that slowly expire and have no chance to get out (Marples 2017).

In the case of Aquinas, there is also a strong emphasis on the role of imagination in the context of developing empathy, the ability to interact with another human being, whose actual state is not available otherwise than through the cooperation of the senses and imagination (ST II-II, q.30, a.1, ad 3). Compassion and the sharing of experiences are 
born of the ecstatic nature of love, which does not stop on itself, but goes out to the other (Ryan 2010; Keaty 2005).

\section{Imagination as a Matter of Virtue: How Imaginary Art Is Born?}

Aquinas connects the imagination with virtues in many ways, acknowledging that there is a relationship between them, and that it is possible to improve the imagination. On the one hand, imagination is needed when it comes to knowing the purpose-finis (which the human person does not yet have, because the whole action is aimed at achieving it, but it is in the subject). It must have some idea of the purpose it is aiming at (Boland 1996). On the other hand, it is about moral virtues that concern the lustful sphere of the human being. Experience shows that the impact of feelings on the ability to evaluate can either be negative or positive, and the acquisition of knowledge or awareness has two stages: inventio and disciplina (ST I, q. 84, a. 3; De veritate, q.11, a.1; Whitfield 2020). In the human being, the investigation for the truth is influenced by feelings, and the imagination contributes to the formation of feelings (by building true or false images of events), whereas these can be an obstacle in learning the truth (ST I-II, q. 77 a. 1c; Vijgen 2018; Brook 2018; Maqueo 2020). Cognitive implications appear not only from the lack of reign (royal or political) of the will and mind in the sphere of feelings, but also because of the vehementem et inordinatam apprehensionem imaginationis, which distorts the judgment of reason. In the fight against distractio, the inner senses play a huge role, especially the resources of the imagination that guide feelings and help to focus on the subject of research. The proper functioning of these senses is a guarantee of a correct learning and what Aquinas understands as speculatio (and speculari divina $)^{1}$. Imaginary art thus remains a tool for developing a cognition of wisdom in a human being, which consists in getting to know-in the light of the ultimate causes (and not just of loved ones) - the skill of macro-explanation, that is, a global view. It is not only about knowing the details of the image (its chemical composition), but what the picture is about (McGrath 2019).

\section{Art as Perfecting the Imagination}

Describing the educational role of aesthetic cognition, Aquinas speaks of a special virtue that perfects the understanding of such cognition, namely the virtue of art (ars) (De Haan 2015). It is defined by Aquinas as "the right reason about certain works to be made" (ratio recta aliquorum operum faciendorum), theoretical efficiency regarding the creation of works, but also as a kind of speculative habits (habitus operativus) (ST I-II, q. 57, a.3c ${ }^{2}$ ). Ars in terms of Aquinas points to a certain order, and thus combines art with purpose. It is not its task to shape the will of the human being (this is the task of moral virtues), but it concerns the goodness of the work itself, and thus the practical abilities. For Aquinas, art is "the principle of perfecting what it refers to", which he defines as "the proper ability to create external works" (ST I-II, q. 57, a. 4c). It is not only about the externality understood in a materialistic way, because the products of the intellect (i.e., syllogisms) are also a manifestation of art for him. Production is associated with a certain purpose, which reveals perfecta ratio (principle of perfection) or recta ratio. It is about discovering deep structures that can be made by mixing colors, breaking patterns-as with many creators, it is not an expression of boredom, but an active search.

Therefore, it is about recte iudicandum de imaginatis, which does not remain without the ethical evaluation of the work. This is indicated by his Summa Theologiae, where he emphasizes the importance of intellectual virtues, which ensure that the imagination does not fall into the wrong direction: "The same applies to the intellectual habits, which render the human being ready to judge aright of those things that are pictured by his imagination. Hence when he ceases to make use of his intellectual habits, strange fancies-sometimes in opposition to them-arise in his imagination; so that unless those fancies be cut off or kept back by frequent use of his intellectual habits, the human person becomes less fit to judge aright, and sometimes is even wholly disposed to the contrary" (ST I-II, q. 53 a. 3c). 
Hence, for Aquinas, imagination or vis imaginativa becomes an effective educational device as far as it is influenced by intellectual virtues. Imagination plays a key role in its epistemology, and is above all stimulating the cogitatio, but also moving the realm of feelings: it is to serve the truth (Dutkiewicz 2018). It will be an attempt to capture the situation in the schema (framework). Aquinas sometimes refers to such "fictional" situations as a philosophical method of behavior, which today takes the form of thought experiments. These similitudines develop or extend the moral sensitivity to situations but "not directly".

On the basis of considerations about charisms (prophecy), Aquinas points not only to the perfection of the imagination (through which a person can guess the future, always with the role of experience), but also stresses that the imagination is dynamic because ideas are transformed (like letters forming words)—sometimes external factors decide about it (sleep, madness) and sometimes the command of reason (imperio) (ST II-II, q. 173, a. 2c; Gómez and Montoya 2021). It distinguishes the imagination of a human from an animal that also senses future events, but does not give into the mind as a human. Reflections worthy of attention can be found in the third part of the Super Boethium de Trinitate, where Aquinas points to the fact that although the imagination is necessary in the present state of the human intellect in order to learn reality, in the light of de divinis, however, the imagination cannot constitute the "end". It has to be unblocked at some point, but cannot disappear. The imaginative species are still present in reasoning (just as the "rules of commands" do not disappear when the right command is carried out): thinking about the incorporeality is possible as long as the image of the body is present in the intellect, to quote Aquinas' example (Super Boethium de Trinitate pars 3 q. 6 a. 2 ad 6). The imaginative art, in the spirit of Aquinas' words, would teach a deeper vision of the world and not reduce it to what is conceivable (conmensurata), but transcend this mensura. This is the case when a person, on the basis of the effects, learns something about a cause that is not commensurate with the result, being "something more" (excellens). This principle of the use of imagination can be expressed by Aquinas' juxtaposition: the imagination is used sicut principiis [...], sed non sicut terminis. In this way, art is an attempt to capture what is inexpressible, to open to what exceeds the human person, but not reduce it to its own level. It becomes in a way the opening of freedom for the human being who is, above all, connected with the soul (Karwasz 2018).

\section{Moral Imagination and Art}

Thomas Aquinas frequently emphasized that bad ideas can direct people to wrong behavior. The ability to imagine oneself in different contexts provokes the very questions of the Summa Theologiae and leads to discovering morality in the key of imitating a person rather than obeying norms (formalism). Mark Johnson even introduces the term "imaginative rationality" (Johnson 1993, p. 200), which allows participation in the world of the other person (Horvat and Pavlic 2020). Imagining oneself in a different situation develops a moral sensitivity: morality appears as art, thus the ability to build the good in a human being. It is worth noting, following Nicolas Steeven, that the imagination (called by him "analogous") is needed to follow Christ: the sequela Christi demands this constant effort (Steeves 2016, pp. 399-406).

Knowledge, born of such a transfer into a different context, becomes imaginary: many times, Aquinas' analyses lead to the presentation of various options of action, of which prudence indicates the right one (Mróz 2001). Imaginative art will be an attempt to assist in building an authentic vision of the world in a faithful way (fidele), in a situation where there are general rules, not an algorithm. This is capturing the complex reality in a creative way that leads to action. There are many restrictions in this way. By perceiving morality as art in this way, M. Johnson draws attention to its five elements: discernment, expression, investigation, creativity, skill. It is about a certain way of organizing variables (contingencies) of events, introducing some control over them, becoming familiar with them. It is a step (near longanimitas) that is a detachment from a blind dependence on 
here and now (Orłowski 2018). Considering morality as art, he states: "This is a kind of skill; that is, an elusive type of knowledge of how to go, in the midst of contingencies and unforeseen circumstances, to realize well-being" (Johnson 1993, p. 214).

\section{Criteria for the Moral Evaluation of Imaginative Art}

It is worth taking into account the moral evaluation of imaginative art and its influence on shaping character. Although Aquinas does not explicitly address this issue, it is possible to indicate a few principles that can be applied to the assessment of non-narrative art. Their role is to "transcend" (transcendere, although sometimes Aquinas uses excedere-see Super De Trinitate, pars 3 q. 6 a. 2c), which corresponds to the fifth category of knowledge, that is, sapiential science (Sententia Ethic., lib. 6 1. $7 \mathrm{n}$. 17). In terms of moral reflection, it should be noted that art does not refer directly to morality, although it refers to the "external" good (work of art) and the internal prudence of the artist $^{3}$. The closeness of considering both topics in the Summa Theologiae seems to suggest Aquinas' answer that when it comes to the absolute, the human good should be taken into account.

Recently, Daniel J. Simpson (2018) referred to the current state of debate on the relation of art and morality, between autonomy and moralism, in both cases with the variant radical and moderate. According to these two views, art cannot be evaluated morally at all (autonomism) or its value reduced to moral values (moralism). He rightly points to the "analogous" understanding of the good (hierarchy of goods, etc.), which allows the settling of old disputes regarding the reasonableness of the proposed distinctions on aesthetic and moral values. Such a division allows Aquinas to see the moral good and the aesthetic not as separated from each other, but two ways of predicate on the same goodness, though in a different way. Aquinas knows that these are things that are not self-sufficient and, to some extent, incomparable, but related. That is why he thinks that "beauty is a mode of goodness, a posterior to and dependent on the virtuous ones" (Simpson 2018).

\subsection{Purpose}

The evaluation criterion of art is its beauty, goodness, utility, understood not in a subjective but metaphysical key (ST I-II, q. 57, a. 3c.; O'Reilly 2007; Ramos 2012). In practice, Aquinas is less concerned about the "feelings" of the work than its objective goodness. The criterion will be based on the extent to which a given manifestation of art leads-to the "ability to act and create" (In 2 Sent., d. 20 q. 2 a. 1 ad 2). That is why the assessment of imaginative art in Aquinas is somewhat a double-track: first, it is assessed through the prism of love, justice, prudence and purity, and second, to what extent it serves these values-is an important criterion of good art.

It does not concern the artist's feelings towards his work, but the quality of the work, as far as the truth is captured in it. It can be said that art (and aesthetics) is the way to discover a sensible order and a coherent vision of the world. Exploring the imagination is not an "escape", but opportunities for action, establishing new relationships. The artist's work is included in the dispositio of individual parts that are intended to serve a certain purpose or intention. The example that Aquinas uses to explain this idea is a glass saw, which, although it may aesthetically seem beautiful (glass seems to be a more beautiful material than iron), would not be the same because of the breaking of the relationship to the purpose of the saw and therefore it is made of iron (ST I, q. 91, a. 3c; Eco 1988, p. 181). Of course, the artist can create whatever he wants in his fantasy, but that means cutting off art from its social meaning. In other words, Aquinas does not seek beauty in isolation from the truth about things, but artistic objects have a function (Saranyana 2003; Amar Diaz 2018). Thomas Storck demonstrated this on the basis of relations between poetry and music, which complement each other over the centuries: their divorce was a consequence of breaking social contexts and poetry became a solitary act (Storck 2011). 


\subsection{Beauty}

The second criterion is the value of beauty. Morally, good imaginative art not only develops human virtues, but also brings out beauty (based on claritas, integritas, proportio), revealing the imperfection of natural forms and directing the human being towards the future (Jaroszyński 2011). In this way, art becomes the norm of life sub specie aeternitatis.

Aquinas defends the autonomy of art, but warns against its absolutization, which would like to make it independent of morality. In order for art to become morally good, the artist must have a good will and therefore have moral virtues. However, the work is indirectly evaluated in relation to morality, as far as it relates to the absolute good of the human person. Therefore, prudence plays a special role here, which refers to the inner good of the human (whereas art refers to the external good). The moral good of the human being is a greater measure than the good (value) of a work of art. At the same time, Aquinas does not understand beauty in the key of contemporary aesthetics, which break away from nature and limit to the fidelity of certain canons of subjective feeling: it must flow out and shape what a given being is by nature.

\subsection{Perfection}

On the basis of links to prudence, Aquinas observes that art and prudence "perfect the soul in the field of beliefs and relations to contingents" (ST, I-II, q. 57, a. 4, ad 2). Therefore, they refer to the matter that he describes as opinativa and contingens, and by their nature, variable, elusive. It is similar to building on a swamp that is on a continuous path and although there is a certain synthesis, it is, however, provisional. It is significant to draw attention to the space in which art moves the world of human opinions, the various views of the same, a multitude of looks that do not want to be reduced to something. The multiplicity in Aquinas' thought has a positive meaning, because it introduces, apart from the good of something individual also the good of the whole, bonum ordinis.

\section{Conclusions: The Role of Art in Shaping Character}

It is worth noting that Aquinas' reflections on art concern a certain efficiency, and therefore not a single act, but a habitus, repetitive, which shapes a certain way. Art in his approach does not directly improve the human person himself, but his creations. It does not consist of a simple mapping of nature, but of the search for rectus, and that is perfection, compliance with the measure. Aquinas even speaks of fidele as the attitude of the artist, "faithfully" performing the work. Here are some concluding remarks.

\subsection{What Virtues Does a Well-Configured Imagination Develop?}

Aquinas emphasizes that the good will is essential for the good use of art and is therefore a condition for its proper application. Although, any (good or bad) attitude of the artist's will is formally not included in the virtue of art; nevertheless, moral virtues building this "good will" are necessary for the good use of art (ST I-II, q. 57, a. 3, ad 2). Therefore, even though Aquinas does not directly mention this, it clearly implies that there is a connection between a morally good life (virtuous) and the value of works performed by the artist. In terms of educating the imagination, intellectual and moral virtues, reason and will are to prevent the imagination from turning into something opposite to reason. For Aquinas, it is not an independent force, but it is regulated by reason and will. This resembles a river that has to be regulated in order to avoid dangerous floods.

\subsection{Harmony of the "Thomistic Symphony"}

Each time Aquinas considers an issue, such as nature and the relationships of a virtue, he always tries to see it in relation to other virtues. According to St. Thomas, there is no use in analyzing it separately by reducing everything to one simple solution, but to indicate that a human being develops in holistic way, since it is impossible to gain perfection in just one virtue. His reflections on imagination do not want to dominate over others, but to put together an orchestra, leaving each at its own level. It is therefore important to develop 
one's imagination because of its educational nature, but also to keep it within limits so that it does not go beyond the limits. One has to form and manage it, because internal images go into external activities. It is not about having a rich imagination, but about its relationship with the intellectual judgment.

Art has the potential of providing imaginative insights, due to which many experiences can become habits. Imaginary art helps to "refine" the moral apprehension and its consequences, and thus has the ability to strengthen moral sensitivity.

\subsection{Art as a Social Act: Teleological Aspects}

In terms of Aquinas, art is not about the self-expression of the artist because there is a pedagogical purpose in art. Therefore, building a character is not a priority for one kind of art or another, but for restoring it to the former ground from which it was "exaggerated" and could not grow roots in a barren land.

However, it is worth paying attention to one more charitable aspect of art, as Aquinas sees it. It concerns the importance of what is universal. This is the stage of spiritual growth (to which faith leads) to see universality, that is, what is general. This testifies to the magnitude of a rational creature that is able to know what is general and therefore can relate to God in the act of faith. It is possible because rational nature "creates a general concept of the good and being" and thus learns about the universal source of being (ST II-II, q. 2, a. 3c). This means a certain path on which the human being experiences "transcendence" (altiori modo) and "enlargement" (ad plura) in relation to what can be a purely rational cognition based on his inquiring about the transition from creatures to God (Kutarňa 2020; Torrijos-Castrillejo 2020; ST II-II, q. 2, ad 3). After the times of Occam's razor, which rejected unnecessary universals, are not precisely the arts developing this sensitivity to the general?

Author Contributions: Formal analysis, P.R., J.A.B.; writing—original draft preparation, P.R.; writingreview and editing, J.A.B. Both authors have read and agreed to the published version of the manuscript.

Funding: This research received no external funding.

Conflicts of Interest: The authors declare no conflict of interest.

\section{Abbreviations}

\section{ST}

Super

Sent.

Super De

Trinitate

De

veritate

Sententia

Ethic

In

Physic.

Sentencia

De anima
Sancti Thomae Aquinatis, Opera omnia iussu impensaque Leonis XIII P. M. edita, t.4-12: Pars prima Summae theologiae (Ex Typographia Polyglotta S. C. de Propaganda Fide, Romae, 1888-1906)

S. Thomae Aquinatis, Scriptum super libros Sententiarum magistri Petri Lombardi episcopi Parisiensis, t. 1. Ed. P. Mandonet (P. Lethielleux, Parisiis, 1929)

S. Thomae Aquinatis, Opera omnia iussu Leonis XIII P. M. edita, t. 50: Super

Boetium De Trinitate (Commissio Leonina-Éditions Du Cerf, Roma-Paris, 1992) pp. $1-230$.

S. Thomae Aquinatis, Opera omnia iussu Leonis XIII P. M. edita, t. 22: Quaestiones disputatae de veritate (Ad Sanctae Sabinae/Editori di San Tommaso, Roma, 1975-1970-1972-1973-1976) 3 vol. 5 fascicula.

S. Thomae Aquinatis, Opera omnia iussu Leonis XIII P. M. edita, t. 47: Sententia libri Ethicorum (Ad Sanctae Sabinae, Romae, 1969) 2 vol.

S. Thomae Aquinatis, Opera omnia iussu impensaque Leonis XIII. P. M. edita, t. 2: Commentaria in octo libros Physicorum Aristotelis (Ex Typographia Polyglotta S. C. de Propaganda Fide, Romae, 1884)

S. Thomae Aquinatis, Opera omnia iussu Leonis XIII P. M. edita, t. 45/1: Sentencia libri De anima (Commissio Leonina-J. Vrin, Roma-Paris, 1984). 


\section{Notes}

1 ST III, q. 7 a. 8 ad 1: "Potest tamen dici quod, etsi Christus habuit plenam et apertam notitiam quantum ad partem intellectivam, habuit tamen in parte imaginativa quasdam similitudines, in quibus etiam poterat speculari divina". Faith also contributes to the development of imagination. It induces and develops the imagination because there is no other way to capture the mystery. In such a spirit, Aquinas interprets the parables of Jesus, e.g., from Matt 13, which demand the work of the imagination. Thus, both moral virtues (shaping the will) such as intellectual or even theological virtues have reference to the imagination and its actions (Steeves 2016; Delgado-Martos 2020).

2 ST I-II, q.57, a.3c: "ars nihil aliud est quam ratio recta aliquorum operum faciendorum. Quorum tamen bonum non consistit in eo quod appetitus humanus aliquo modo se habet, sed in eo quod ipsum opus quod fit, in se bonum est. Non enim pertinet ad laudem artificis, inquantum artifex est, qua voluntate opus faciat; sed quale sit opus quod facit. Sic igitur ars, proprie loquendo, habitus operativus est. Et tamen in aliquo convenit cum habitibus speculativis, quia etiam ad ipsos habitus speculativos pertinet qualiter se habeat res quam considerant, non autem qualiter se habeat appetitus humanus ad illas. Dummodo enim verum geometra demonstret, non refert qualiter se habeat secundum appetitivam partem, utrum sit laetus vel iratus, sicut nec in artifice refert, ut dictum est. Et ideo eo modo ars habet rationem virtutis, sicut et habitus speculativi, inquantum scilicet nec ars, nec habitus speculativus, faciunt bonum opus quantum ad usum, quod est proprium virtutis perficientis appetitum; sed solum quantum ad facultatem bene agendi".

3 It is significative the Aquinas opinion on the art as intellectual virtue and its relation to good of art and its use: "When anyone endowed with an art produces bad workmanship, this is not the work of that art, in fact it is contrary to the art: even as when a man lies, while knowing the truth, his words are not in accord with his knowledge, but contrary thereto. Wherefore, just as science has always a relation to good, as stated above, so it is with art" (ST I-II, q.57, a.3, ad 1).

\section{References}

Amar Diaz, Mauricio. 2018. Ética de la Imaginación. Averroísmo, uso y Orden de las Cosas. Santiago de Chile: Malamadre.

Bauerschmidt, Frederick. 2009. Imagination and Theology in Thomas Aquinas. Louvain Studies 34: 169-84. [CrossRef]

Bauerschmidt, Frederick. 2010. Imagination and Theology in Thomas Aquinas. Louvain Studies 34: 119-45. [CrossRef]

Boland, Vivian. 1996. Ideas in God According to Saint Thomas Aquinas. Leiden: Brill.

Brook, Angus. 2018. Thomas Aquinas on the Effects of Original Sin: A Philosophical Analysis. The Heythrop Journal 59: 721-32. [CrossRef]

De Haan, Daniel. 2015. Delectatio, Gaudium, Fruitio: Three Kinds of Pleasure for Three Kinds of Knowledge in Thomas Aquinas. Quaestio: Journal of the History of Metaphysics 15: 241-50. [CrossRef]

Delgado-Martos, Emilio. 2020. El espacio expectante. Un acercamiento al espacio litúrgico como lugar de presencia y de encuentro a través de la obra de Rupnik. Scripta Theologica 3: 587-613. [CrossRef]

Dutkiewicz, Tomasz. 2018. Teza o aksjologicznej neutralności uczuć a katolicka nauka o ich roli w życiu moralnym człowieka: Próba antropologiczno-etycznej analizy problemu. Teologia i Człowiek 43: 33-46. [CrossRef]

Eco, Umberto. 1988. The Aesthetics of Thomas Aquinas. Translated by Hugh Bredin. Cambridge: Harvard University Press.

Gilson, Etienne. 1994. The Christian Philosophy of St. Thomas Aquinas. Notre Dame: University of Notre Dame Press.

Gómez, María Teresa Enríquez, and Jorge Martín Montoya. 2021. Imperio y causalidad en Tomás de Aquino. Scientia et Fides 9: 329-55. [CrossRef]

Horvat, Saša, and Richard Pavlic. 2020. Teološka antropologija pred izazovom (evolutivne) kognitivne znanosti o religiji. Diacovensia 28: 303-17. [CrossRef]

Jaroszyński, Piotr. 2011. Beauty and Being: Thomistic Perspectives. Toronto: Pontifical Institute of Mediaeval Studies.

Johnson, Mark. 1993. Moral Imagination. Implication of Cognitive Science for Ethics. Chicago: University of Chicago Press.

Karwasz, Grzegorz. 2018. Aristotle's Three Souls in Modern Science: Re-reading De Anima. Cauriensia 13: 429-58. [CrossRef]

Keaty, Anthony. 2005. The Christian Virtue of Mercy: Aquinas' Transformation of Aristotelian Pity. The Heythrop Journal 46: 181-98. [CrossRef]

Kutarňa, Andrej. 2020. Hierarchy and Likeness-Ways to Union with God in Pseudo-Dionysius and Aquinas. Biblica et Patristica Thoruniensia 13: 189-98. [CrossRef]

Lazaro-Pulido, Manuel. 2019. Mas alla de la quiditas: Reflexiones sobre el proyecto metafisico bonaventuriano. Cauriensia 14: 49-80. [CrossRef]

Manzanedo, Marcos. 1978. La Imaginación y la Memoria Según santo Tomás. Roma: Herder.

Maqueo, David Tellez. 2020. The Vice of Lust and its Impact on Intellectual Knowledge in the Teachings of Some Fathers of the Church. Biblica et Patristica Thoruniensia 13: 341-55. [CrossRef]

Marples, Roger. 2017. Art, knowledge and moral understanding. Ethics and Education 2: 243-58. [CrossRef]

Martinez, Enrique. 2002. Persona y Educación Según santo Tomás de Aquino. Madrid: Fundación Universitaria Española. 
Matula, Jozef. 2002. Thomas Aquinas and the Influence of Imaginatio/Phantasia on Human Being. Acta Universitatis Palackianae Olomucensis, Facultas Philosophica, Philosophica 5: 169-83.

McGrath, Alister. 2019. Narrative Apologetics. Sharing the Relevance, Joy, and Wonder of the Christian Faith. Grand Rapids: Baker Books.

Mróz, Mirosław. 2001. Aktualność aretologii św. Tomasza z Akwinu w świetle pytania o podstawy moralności chrześcijańskiej. Toruń: WSD.

Mróz, Mirosław. 2018. Physiological and Psychological Foundation of Virtues: Thomas Aquinas and Modern Challenges of Neurobiology. Scientia et Fides 6: 115-28. [CrossRef]

O'Reilly, Kevin. 2007. Aesthetic Perception: A Thomistic Perspective. Dublin: Four Courts Press.

Oleksowicz, Michał, and Piotr Roszak. 2021. Plurality as epistemic good. Theological Explanation in Science-Religion Debate. Journal for the Study of Religions and Ideologies 20: 81-95.

Orłowski, Piotr. 2018. Lider a zarządzanie według Tomasza z Akwinu. Studia Włocławskie 20: 539-52.

Platovnjak, Ivan. 2018. The Importance of Imagination in Ignatian Spirituality. Bogolovska Smotra 88: 1035-55.

Ramos, Alice. 2012. Dynamic Transcendentals: Truth, Goodness, and Beauty from a Thomistic Perspective. Washington, DC: The Catholic University of America Press.

Roszak, Piotr. 2020. Mute Sacrum. Faith and Its Relation to Heritage on Camino de Santiago. Religions 11: 70. [CrossRef]

Ryan, Thomas. 2010. Aquinas on Compassion: Has He Something to Offer Today? Irish Theological Quarterly 75: 157-74. [CrossRef]

Saranyana, Josep-lgnasi. 2003. Estética tomasiana y estética musulmana plenomedievales. A proposito del pulchrum. Revista Española de la Filosofia Medieval 10: 303-11. [CrossRef]

Simpson, Daniel. 2018. Reframing Aquinas on Art and Morality. American Catholic Philosophical Quarterly 2: 295-311. [CrossRef]

Steeves, Nicolas. 2016. Grâce à L'imagination. Intégrer L'imagination en Théologie Fondamentale. Paris: Éditions du Cerf.

Stępień, Tomasz. 2013. Wprowadzenie do Antropologii Filozoficznej św.Tomasza z Akwinu. Warszawa: Warszawskie Towarzystwo Teologiczne.

Storck, Thomas. 2011. Seeking Beauty in Art: Some Implications of a Thomistic Statement about Glass Saws. New Blackfriars 92: 431-42. [CrossRef]

Tabaczek, Mariusz. 2020. The Role of Causality in Scientific Models of Explanation in the Context of the Retrieval of the Classical Concept of Divine Action. Scientia et Fides 8: 43-75. [CrossRef]

Torrijos-Castrillejo, David. 2020. Divine foreknowledge and providence in the commentaries of Boethius and Aquinas on the De interpretatione 9 of Aristotle. Biblica et Patristica Thoruniensia 13: 151-73. [CrossRef]

Vijgen, Jörgen. 2018. The Corruption of the Good of Nature and Moral Action: The Realism of St. Thomas Aquinas. Espiritu 155: 127-52.

Waller, Giles. 2018. Felix Culpa? On Rowan Williams' The Tragic Imagination. Modern Theology 2: 243-51. [CrossRef]

Whitfield, Mikail. 2020. Aquinas on Relations: A Topic Which Aquinas Himself Perceives as Foundational to Theology. European Journal for the Study of Thomas Aquinas 38: 15-32. [CrossRef]

Zembrzuski, Michał. 2015. Od Zmystu wspólnego do pamięci i przypominania. Koncepcja zmysłów wewnętrznych w teorii poznania św. Tomasza z Akwinu. Warszawa: Campidoglio. 